\title{
Narrativas institucionais e juvenis a partir da JMJ: emergências de afeto e cultura midiática no catolicismo*
}

\begin{abstract}
Sílvia Fernandes**
\section{Resumo}

Este estudo objetiva analisar as interações discursivas entre o papa Francisco e o segmento juvenil no Brasil durante a Jornada Mundial da Juventude em 2013, mostrando algumas tensões desses discursos. Serão colocadas em pauta as manifestações juvenis provenientes de sites católicos; redes sociais; entrevistas com jovens participantes da JMJ; narrativas na mídia e os discursos oficiais do papa quando remetidos à juventude. Argumenta-se que a linguagem com apelo pastoral tem forte impacto sobre jovens católicos nas redes sociais, bem como, a dimensão afetiva que o papa Francisco explora em suas narrativas, ainda que a sua aprovação não seja unânime entre os entrevistados. Analisa-se ainda que, em tempos de declínio quantitativo do catolicismo na América Latina, o segmento juvenil assume um lugar central nas narrativas institucionais da Igreja Católica, especialmente a partir desse evento voltado para os jovens.
\end{abstract}

Palavras-chave: Igreja Católica. Papa Francisco. Juventude. Mídia.

* Uma primeira versão desse texto foi apresentada sob o título: Francisco: um papa pop? Perspectivas a partir da Jornada Mundial da Juventude no Brasil no XXXII International Congress of the Latin American Studies Association - LASA 2014, Chicago/EUA, no Painel intitulado: Pope Francis and the future of Catholicism in Latin America. Agradecemos os comentários dos colegas Daniel Lévine, Manuel Vasquez, Néstor da Costa e Bryan Fröehle naquela ocasião. Agradecemos a Olga Chiapim (IC/FAPERJ) e Bruno Loura (PIBIC) pela coleta de dados e produção de relatórios analíticos. Parte deste estudo contou com o apoio da CAPES - Estágio Pós-doutoral 2013-2014. Destacamos ainda que, as reflexões no âmbito do Projeto: "As Novas Configurações da Religião no Século XXI": um inventário sobre jovens participantes em megaeventos religiosos", coordenado por Cecília Mariz e Paulo Gracino Júnior (2013), favoreceram o desenvolvimento do presente artigo. Sublinhe-se, contudo, que os dados coletados em tal projeto serão analisados em outra ocasião.

** Universidade Federal Rural do Rio de Janeiro. Dra em Ciências Sociais, professora da Universidade Federal Rural do Rio de Janeiro - UFRRJ. Tem se dedicado a análise do fenômeno religioso no Brasil, especialmente o catolicismo. Realizou pesquisas sobre o clero e a vida religiosa consagrada sob a ótica sociológica. Sua tese doutoral recebeu o Prêmio Editoração FAPERJ 2009 e foi publicada pela Quartet, sob o título: Jovens religiosos e o catolicismo: escolhas, desafios e subjetividades. Atualmente pesquisa Religião e Juventude; catolicismos, pentecostalismos, ateísmo juvenil. 


\title{
Institutional and juveniles narratives from the WYD: emergencies of affection and media culture in catholicism
}

\begin{abstract}
This study intends to analyze the discursive interactions between Pope Francis and the youth in Brazil during the World Youth Day in 2013, emphasizing some tensions of these discourses. Youth manifestations coming from catholic websites will be highlighted; social networks; Interviews with young participants of WYD; Narratives in the media and the official speeches of the Pope when remitted to the youth. It is argued that the pastoral language has a strong impact on young catholic in social networks, as well, as the affective dimension that the Pope Francis explores in his narratives even though his approval is not unanimous among the interviewees. Considering the quantitative decline of Catholicism in Latin America, the youth takes a central place in the institutional narratives of the Catholic Church, particularly from this event addressed to young people.
\end{abstract}

Key-words: Catholic Church. Pope Francis. Youth. Media.

\section{Narrativas institucionales y juveniles a partir de la JMJ: emergencias de afecto y cultura mediática en el catolicismo}

\section{Resumen}

Este estudio tiene como objetivo analizar las interacciones discursivas entre el papa Francisco y el segmento juvenil en Brasil durante la Jornada Mundial de la Juventud en 2013, mostrando algunas tensiones de esos discursos. Se colocarán en pauta las manifestaciones juveniles provenientes de sitios católicos; redes sociales; Entrevistas con jóvenes participantes de la JMJ; Narrativas en los medios y los discursos oficiales del papa cuando se remiten a la juventud. Se argumenta que el lenguaje con el apelo pastoral tiene un fuerte impacto sobre los jóvenes católicos en las redes sociales, así como la dimensión afectiva que el papa Francisco explora en sus narrativas aunque su aprobación no sea unánime entre los entrevistados. Se analiza también que, en tiempos de declinación cuantitativa del catolicismo en América Latina, el segmento juvenil asume un lugar central en las narrativas institucionales de la Iglesia Católica, especialmente a partir de ese evento dirigido a los jóvenes.

Palabras clave: Iglesia Católica. Papa Francisco. Juventud. Médios.

Desde a eleição do papado, ocorrida em 2013, que elevou o cardeal Jorge Bergoglio ao pontificado, a imagem do papa argentino tem sido frequente nos mais diferentes veículos de comunicação e redes sociais. Transpondo significativamente o mero título eclesiástico, o papa Francisco é reverenciado 
por seu carisma ${ }^{1}$ e expressão que gera empatia em diversos segmentos sociais. Em tempos de queda de adeptos do catolicismo na América Latina ${ }^{2}$ atribuída, sobretudo, ao avanço do pentecostalismo, o atual chefe da Igreja Católica parece reanimar ânimos eclesiais e seculares e mobilizar de modo particular o segmento juvenil. O investimento de Bergoglio no quesito pastoral vem de longa data e pode ser confirmado em publicações como Reflexiones sobre la vida apostólica (1986) e Reflexiones de Esperança (1992) sempre destacadas nos trabalhos biográficos sobre o papa Francisco. ${ }^{3}$

A popularidade do papa argentino extrapola o universo da Igreja Católica e ganha espaço em diferentes setores sociais, uma vez que a fórmula simples de suas mensagens, conforme será vista neste artigo, questiona um conjunto de convenções do título que o religioso carrega. Essa dinâmica promove uma espécie de efeito boomerang entre sua imagem e a sociedade, tendo a mídia como simpatizante e forte aliada de Francisco e tendo os segmentos juvenis como um de seus principais públicos simpatizantes.

Cabe ressaltar que a emissão de cartas voltadas aos jovens por parte de chefes da igreja não se configura como um fato exatamente novo. Vários papas fizeram discursos apelando para a energia e responsabilidade juvenil com o futuro das nações e para o cultivo do que denominam "cultura de paz". De modo particular, por ocasião do Ano Internacional da Juventude, em 1985, o então papa João Paulo II escreveu uma carta direcionada aos jovens, na qual são tratadas questões relacionadas aos valores juvenis; moral e consciência;

1 Neste trabalho adotamos o conceito de carisma de acordo com a perspectiva de Max Weber em seus estudos sobre dominação. Weber argumenta que na dominação carismática o líder alcança uma devoção afetiva por parte de seus seguidores. Segundo o autor, de tempos em tempos surgem líderes que "antecipam o padrão moral de uma época posterior, lançam conceitos de virtude desinteressada, de filantropia, de desprendimento que parecem não ter relação com o espírito de sua época, inculcam deveres e sugerem motivos de ação que parecem à maioria dos homens completamente quiméricos. Não obstante, o magnetismo de suas perfeições influi poderosamente sobre os seus contemporâneos" (WEBER, s.d. apud Gerth; MILLS, [1946] 1982). Gerth e Mills citam como fonte primária o texto de Max Weber intitulado Jugendbriefe, publicado em Tübingen, sem data de referência.

2 Uma ampla pesquisa sobre cenário religioso na América Latina foi realizada pelo Pew Center em 2014. Os dados demonstram queda relativa dos que se declaram católicos em dezenove países latino-americanos. Disponível em: http://www.pewforum.org/2014/11/13/ religion-in-latin-america/ Acesso em 16 ago. 2016.

3 A SANTA SÉ. Biografia do Santo Padre Francisco. Vaticano (2013). Disponível em: https://w2.vatican.va/content/francesco/pt/biography/documents/papa-francesco-biografia-bergoglio.html. Acesso em 8 abr. 2015. 
desafios do futuro, entre outros temas, cuja abordagem assume sempre um tom de aconselhamento e orientação (CNBB, 2012).

A depender do momento histórico, cada carta ou texto direcionado aos jovens enseja determinada nuanças e não há meios de mensurar com precisão o quanto essas narrativas de fato alcançam ou impactam os jovens católicos; se eles leem esses textos e qual seria o grau de circulação dos mesmos no universo frequentado por diferentes grupos de jovens.

As Jornadas, entretanto, permitem observar o que denominamos interações discursivas entre o papa e os jovens. Entendemos que muitos deles são atraídos pelos discursos do papa e o evento religioso instiga a análise sobre o quanto determinadas narrativas sobre valores, responsabilidades, compromissos sociais etc. advindas do chefe da igreja encontram ressonância na vida prática e na experiência religiosa dos segmentos juvenis que, de algum modo, se aproximam da Igreja Católica por ocasião do evento.

Este texto, de caráter exploratório, analisa as narrativas do papa Francisco aos jovens por ocasião da JMJ no Rio de Janeiro, Brasil, articulando perspectivas estratégicas do catolicismo no mundo, a partir dos discursos para, sobre e com a juventude. $\mathrm{O}$ fato de ter sido realizada uma pesquisa qualitativa com jovens da cidade que atuaram nas Jornadas justifica nosso recorte nesta edição do evento e não na edição realizada em Cracóvia, na Polônia, no ano de 2016.

Neste trabalho, são analisadas as interações discursivas entre o papa e os jovens, buscando compreender suas características e apontando alguns caminhos interpretativos. Como sobrescrito, as principais fontes de informações que embasam o artigo são os textos papais nas Jornadas e a pesquisa qualitativa realizada durante a JMJ no Rio de Janeiro com cinquenta jovens. ${ }^{4}$ A essa fonte foram agregadas outras bases de dados de estudos mais amplos sobre a juventude, religião (FERNANDES, 2009; 2011) e a respeito da inserção da Igreja Católica nos meios de comunicação (DELLA CAVA; MONTERO, 1991). Como o texto discute os textos do papa e documentos da igreja divulgados pela grande mídia, o leitor encontrará um conjunto de indicações de websites em notas de rodapé. Alerta-se para o fato de que essas indicações, longe de representar uma pesquisa superficial na internet, visam tão-somente facilitar o acesso do leitor a documentos e textos tratados no presente trabalho.

\section{Jornadas da juventude - contextualização}

4 Foram realizadas cinquenta entrevistas, mas apenas 47 foram usadas nesta análise em função da deficiência de informações em três delas. 
A JMJ - Jornada Mundial da Juventude - acontece anualmente nas dioceses católicas em todo o mundo, mas a presença do papa nos eventos segue uma periodicidade de dois a três anos, tendo o último evento ocorrido em Cracóvia, na Polônia, em julho de 2016. Em geral, cada edição tem a duração de uma semana, mas envolve uma superestrutura que se consolida nos dois anos que o antecedem.

O lema da $28^{a}$. edição realizada na cidade do Rio de Janeiro, em 2013, foi: "Ide e fazei discípulos entre todas as nações", inscrição bíblica que expressa a expansão da religião por meio de diferentes estratégias de difusão. Percebida por setores católicos como "a maior reunião de jovens católicos do mundo", 5 a Jornada objetiva exatamente sensibilizar os segmentos juvenis para a expansão da mensagem católica, atraindo eventualmente novos jovens.

A origem da JMJ está nos grandes encontros com jovens, celebrados pelo papa João Paulo II, em Roma. Por ocasião do chamado Ano Santo da Redenção, o primeiro Encontro Internacional da Juventude aconteceu em 1984, na Praça São Pedro, no Vaticano, reunindo 300 mil jovens de várias partes do globo. Foi naquele momento que o papa entregou aos jovens a cruz, símbolo principal da Jornada. No ano seguinte, 1985, a ONU - Organização das Nações Unidas - declarou o Ano Mundial da Juventude e o papa anunciou, em outro encontro internacional com jovens no Vaticano, a institucionalização da Jornada Mundial da Juventude.

O evento é de natureza global e foi sediado pelos seguintes países: Polônia, Estados Unidos, França, Alemanha, Canadá, Argentina, Austrália e Filipinas. A Jornada em Manila, nas Filipinas, concentrou quatro milhões de jovens, estabelecendo, assim, o maior público até a Jornada de 2013. A antepenúltima edição internacional da JMJ ocorreu em agosto de 2011, na cidade de Madri, Espanha, e contou com a participação de mais de 190 países. No Brasil, na cidade do Rio de Janeiro, a JMJ reuniu 3,5 milhões de pessoas ${ }^{6}$ e na edição ocorrida na Polônia, houve aproximadamente dois milhões de jovens. ${ }^{7}$

Em 2003, o papa João Paulo II deu aos jovens um segundo símbolo para

CANÇÃO NOVA. Entenda o que é a Jornada Mundial da Juventude. São Paulo, (2016). Disponível em: https://noticias.cancaonova.com/especiais/jmj/cracovia-2016/entenda-oque-e-a-jornada-mundial-da-juventud. Acesso em 16 jul. 2017.

6 Números divulgados pela Agência Ecclesia. Disponível em: http://www.agencia.ecclesia. pt/noticias/vaticano/jmj-2013-37-milhoes-de-pessoas-na-missa-final-da-jornada-mundialda-juventude. Acesso em 12 mar. 2014.

7 De acordo com notícia veiculada pelo Comitê Organizador Local, em Cracóvia. Disponível em: https://noticias.cancaonova.com/especiais/jmj/cracovia-2016/coordenador-geralfaz-balanco-da-jmj/ Acesso em 12 jul. 2017. 
acompanhar a cruz na JMJ: o ícone de Maria, "Salus Populi Romani" (protetora do povo romano). Trata-se de uma cópia contemporânea de Maria com o menino, nomeada no século XIX, e que atualmente é exibida na Basílica de Santa Maria Maior, em Roma. O ícone quer significar a presença de Maria próxima aos jovens que, por sua vez, são convocados a essa devoção. Obviamente, o ícone expressa ainda que, além de uma Jornada voltada para jovens cristãos - representados exclusivamente pela cruz - tem-se uma Jornada para jovens católicos, sendo Maria o principal símbolo delimitador das fronteiras entre o catolicismo e outras expressões do cristianismo. Outros autores que estudaram o tema argumentam que o evento está focado na juventude católica (GONZALEZ, 2016).

No Rio de Janeiro, o Comitê Organizador da JMJ empenhou-se na divulgação do evento, enfatizando que haveria "testemunhos de fé", festivais musicais, atividades de difusão da fé católica, como a chamada "catequese", além de atividades culturais. A ideia seria estabelecer "exemplos de amor ao próximo e à igreja” visando mais uma vez a juventude.

Após essa breve contextualização, cabe uma análise da juventude católica no quadro mais amplo de situação do catolicismo no Brasil, com ênfase no caso do Rio de Janeiro, cidade anfitriã da versão da JMJ em 2013.

O Rio de Janeiro destacou-se no cenário mundial por sediar megaeventos, como a Copa do Mundo, em 2014, e os Jogos Olímpicos, em 2016. A escolha do município como cidade sede para a JMJ, em 2013, sugere uma estratégia institucional diante da situação do catolicismo no Estado, conforme descrição a seguir.

De acordo com o censo do IBGE - Instituto Brasileiro de Geografia e Estatística, realizado em 2010, o Estado do Rio de Janeiro apresentou a menor população católica 45,8\% (7.324.315) em todo o Brasil (64,6\%), e, além disso, possui o maior número de pessoas que se denominam "sem religião" 15,6\% (2.493.704) quando a média nacional é de 8\%. Tomando-se o segmento juvenil que se declara sem religião, o Estado do Rio apresenta uma taxa de 19,8\% de jovens na faixa etária entre 15 a 19 anos. Nessa mesma faixa, em abrangência nacional, os sem religião totalizam 10,1\%.

O atual cenário de desfiliação religiosa da juventude brasileira e, particularmente, fluminense, pode ter chamado a atenção da Igreja Católica para criar um ambiente propício à realização da JMJ na cidade - que é também conhecida como a capital cultural -, tendo o papa mencionado em um de seus 
discursos na JMJ que os jovens "perderam a fé em Deus". ${ }^{8}$ Não obstante, com esse evento a igreja demonstrou alta capacidade de mobilização, que pode eventualmente alcançar índices mais favoráveis para o catolicismo no Estado, diante do declínio que vem ocorrendo há décadas. A JMJ, sobretudo em razão da presença do papa Francisco, fez que a Igreja Católica ganhasse visibilidade social, sendo reinscrita na cena pública com um símbolo que parece abrandar sua imagem negativa evidenciada nos últimos anos, sobretudo em razão dos escândalos do clero.

\section{O Papa, sua "revolução" e o catolicismo}

Jorge Mario Bergoglio, o papa Francisco, assume o poder em um momento crítico da Igreja Católica, em função da queda no número de fiéis que atinge toda a América Latina (FERNANDES, 2006; 2013; PEW CENTER, 2014) e ainda por escândalos no Vaticano envolvendo temas fortes para uma instituição religiosa: corrupção e pedofilia.

Esse quadro vem sendo exaustivamente explorado pela imprensa, ${ }^{9}$ incluindo-se a repercussão de filmes ${ }^{10}$ sobre casos de pedofilia na Igreja Católica. De modo particular, questões que envolvem a diminuição de católicos na América Latina e no Brasil são temas constantes no debate acadêmico tanto na sociologia quanto na antropologia e ciências da religião (TEIXEIRA; MENEZES, 2013) e, em 2014, foi objeto de um survey dirigido pelo Pew Research Center. A pesquisa desse centro de investigações norte-americano mostrou que em dezenove países latino-americanos há crescimento do pentecostalismo e diminuição do número de católicos, que totalizam $69 \%$ em toda a região e 61\% no Brasil (PEW CENTER, 2014).

A situação do catolicismo, entretanto, pode ser avaliada sob vários ângulos. Se, por um lado, a capacidade institucional de atrair novos adeptos aparece mais rarefeita, tendo em vista a persistente queda no número dos que

8 Durante a Via Sacra com os jovens, em Copacabana, Francisco afirma que alguns jovens perderam a fé nas instituições políticas e em Deus por causa da "incoerência dos cristãos". Disponível em: https://goo.gl/c8W4uH. Acesso em 24 jul. 2017.

9 Ilustrando apenas a partir de alguns jornais internacionais, as notícias sobre Vatleaks envolvendo corrupção e ainda os inúmeros casos de pedofilia na Igreja Católica podem ser encontrados em http://www.theguardian.com/world/2012/may/28/vatileaks-scandal-pope-butler-gabriele. Acesso em 15 ago. 2013; http://www.washingtontimes.com/ news $/ 2013 /$ jul/2/new-yorks-cardinal-dolan-accused-shielding-pedophi/. Acesso em 2 jul. 2015 e http://elpais.com/tag/vaticanleaks/a/. Acesso em 20 nov. 2015.

10 Spotlight-segredos revelados, sob a direção de Tom McCarthy. Indicado ao Oscar 2016 como melhor filme e vencedor do prêmio. 
se declaram católicos, por outro, no catolicismo que resiste, há potenciais formas de expansão, sobretudo a partir das novas modalidades de associações e comunidades religiosas, como as chamadas Comunidades de Vida no Espírito Santo (FERNANDES, 2011; 2013; MARIZ, 2005) e ainda nas tradicionais comunidades de base que se mantêm articuladas a partir de encontros intereclesiais. A menção à resistência católica justifica-se pelo fato de que, em um mesmo Estado como o do Rio de Janeiro, há cidades em que o catolicismo resiste à tendência de declínio quantitativo de adeptos em razão da tradição local ou até mesmo por questões demográficas (FERNANDES, 2013).

No entanto, cabe chamar atenção para o que parece uma consolidação do ethos carismático entre boa parte dos católicos no Brasil, fato constatado nas celebrações e atividades religiosas que marcaram a JMJ. Alguns autores consideram inclusive que a JMJ consolidou o estilo Gospel no catolicismo do país (CARRANZA, 2013). ${ }^{11}$ Esse tipo de constatação não significa, contudo, que o catolicismo não mantenha a sua diversidade interna, mas, ao que parece, a expansão de TVs católicas, de padres cantores e das diferentes modalidades de associação de fiéis apresentam-se como um desafio aos setores da Igreja Católica que se mostram mais simpáticos aos ideários apregoados pela Teologia da Libertação, notadamente mais proeminente nos anos de 1980.

A postura e o estilo de vida do papa Francisco - especialmente quando comparado ao seu antecessor Bento XVI - cativaram diversos setores da sociedade em vários países. Mídia, governos e cidadãos comuns, católicos ou não, tendem a emitir uma visão positiva sobre o papa Francisco e ressaltam principalmente duas entre as que seriam suas virtudes: austeridade e humildade. ${ }^{12}$ Alguns entendem que o atual pontífice estaria realizando uma revolução na Igreja Católica a começar pelo papado e pela cúria romana. ${ }^{13}$ Francisco, a

11 INSTITUTO HUMANITAS UNISINOS. São Leopoldo (2013). Disponível em: http://www.ihu. unisinos.br/entrevistas/522322-as-intervencoes-do-pontifice-mudaram-de-tom-da-presenca-teologica-para-o-contato-pastoral-entrevista-especial-com-brenda-carranza. Acesso em 10 ago. 2013.

12 O Jornal O Globo destacou o que considerou ser dez "atitudes de humildade" do papa Francisco. Entre essas foram mencionadas a escolha do papa Francisco em lavar os pés de doze jovens infratores em um reformatório italiano e o fato de ter escolhido residir na Casa Santa Marta abrindo mão do apartamento papal no Vaticano. Disponível em: https://oglobo.globo.com/ mundo/dez-atitudes-de-humildade-do-papa-francisco-10008671. Acesso em 23 jul. 2017.

13 Confira a matéria do Jornal El País em que o jornalista Daniel Verdú exalta a linguagem gestual do papa: "No fim das contas, a narrativa constituída por um abraço a um doente grave de neurofibromatose - a imagem correu o mundo — pode ser mais poderosa do que uma encíclica”: https://brasil.elpais.com/brasil/2017/03/13/internacional/1489410017_522519.html. Acesso em 18 jun. 2017. 
partir de uma narrativa mais direta, com expressividade corporal tipicamente latina e com uma carga de afeto que se manifesta pela proximidade com o seu público, criou uma espécie de consenso junto ao senso comum. Contudo, é importante sublinhar que não há consenso no universo eclesiástico e eclesial a respeito do papa argentino, uma vez que ele tem sido duramente criticado por clérigos e leigos. Na visão do historiador Massimo Faggioli (2015), Jorge Bergoglio é contestado política, teológica e institucionalmente por seus opositores, mas haveria uma simpatia da imprensa em relação a ele que tende a se expressar mais livremente em relação a temas polêmicos nas entrevistas concedidas a jornalistas em viagens, ocasião em que, segundo o historiador, o papa se permitiria tratar de temas espinhosos ou "diferentes".

Na Jornada Mundial da Juventude ocorrida no Rio, entretanto, ficou evidente que o papa Francisco conclama para uma espécie de "revolução do coração", em que a evangelização e a difusão do catolicismo, a partir da missão, constituem-se como seus mais fortes objetivos. Note-se que a disposição de Francisco para demonstrar afeto, tocando as pessoas, beijando crianças e chorando com elas - como visto no Brasil e em outros países por ele visitados - denuncia, de certo modo, algumas limitações das paróquias e da estrutura eclesial. Em geral, essa estrutura é mais fria e impessoal, carregada de tarefas e cumprimento de atividades religiosas, o que dificulta um maior engajamento de boa parte do clero católico no cotidiano dos fiéis (VASQUEZ; FERNANDES, 2013).

$\mathrm{Na}$ verdade, em seu discurso aos jovens argentinos no Rio, o papa afirmou: "[...] quero que saiam, quero que a Igreja saia pelas estradas, quero que nos defendamos de tudo o que é mundanismo, imobilismo, nos defendamos do que é comodidade, do que é clericalismo, de tudo aquilo que é viver fechados em nós mesmos". ${ }^{14}$ Não seria demais recordar que em estudos qualitativos, sobretudo no Rio de Janeiro, os fiéis reclamaram da falta de tempo e de atenção dos padres ou ainda a falta de acolhimento na Igreja Católica (FERNANDES, 2013).

Com efeito, o chamado de Francisco para a "revolução" é diferente dos protestos de rua frequentes no Brasil, particularmente durante o mês de junho de 2013, período coincidente com as Jornadas e, em 2016, quanto ao movimento juvenil de ocupação das escolas ou mobilizações pró e contra o impeachment da então presidente Dilma Roussef. Ainda que o papa

\footnotetext{
14 A SANTA SÉ. Encontro com os jovens argentinos - palavras do Santo Padre. Disponível em:https:// w2.vatican.va/content/francesco/pt/speeches/2013/july/documents/papa-francesco_20130725_gmg-argentini-rio.html. Acesso em 15 dez. 2013.
} 
Francisco tenha reconhecido o direito das pessoas ao protesto de "forma ordeira, pacífica e responsável", o foco de sua convocação à revolução é o "coração" das pessoas e da juventude. Francisco sugere uma "revolução do coração" que pode trazer mais fé, amor e solidariedade para um mundo em que há mais ceticismo e indiferença religiosa e no qual "os jovens perderam a fé na Igreja, ou mesmo em Deus pela incoerência de cristãos e ministros do evangelho". ${ }^{15}$ Em outras palavras, a chamada para a revolução é primária e fundamentalmente uma chamada à evangelização. Nesse sentido, é possível identificar continuidades entre a crítica de Francisco à "cultura do egoísmo e individualismo" e as denúncias de Bento XVI e João Paulo II de "ditadura do relativismo" e a "cultura da morte" (VASQUEZ; FERNANDES, 2013).

O "coração" como uma forte metáfora é constantemente acionado pelo papa Francisco em situações diversas. Ao receber, em Roma, os membros do comitê organizador das Jornadas no Rio, ele afirmou:

Quando cheguei ao Brasil, no meu primeiro discurso oficial, disse que queria ingressar pelo portal do imenso coração dos brasileiros pedindo licença para bater delicadamente à sua porta e passar a semana com o povo brasileiro. Porém, ao término daquela semana, voltando para Roma, cheio de saudades, dei-me conta de que os cariocas são uns "ladrões"! Sim, "ladrões", pois roubaram o meu coração! $!^{16}$

A presença do papa Francisco no Brasil demonstrou ainda a sua habilidade em fazer convergir duas correntes pastorais internas ao catolicismo que têm estado em permanente conflito nos últimos anos na América do Sul. Desse modo, a "opção preferencial pelos pobres" - aspecto fundamental da teologia progressista - tem sido reinventada sob a chave da intimidade da "cultura de encontro" e a afetividade catártica do movimento de Renovação Carismática Católica - RCC, ainda que tenha evitado a ostentação que muitas vezes acompanha o último. É um carismatismo inscrito numa gramática da simplicidade (VASQUEZ; FERNANDES, 2013). Nesse conjunto, predominam a ênfase pastoral e a afetividade como elementos que têm favorecido a popularidade do papa Francisco em diferentes partes do globo.

\footnotetext{
15 O discurso na íntegra está disponível em: http://www.news.va/pt/news/na-via-crucis-papafrancisco-fala-dos-jovens-que-p . Acesso em 12 jan. 2014.

16 Disponível em: http://jovensconectados.org.br/ao-comite-organizador-da-jmj-papa-repete-os-brasileiros-roubaram-o-meu-coracao.html. Acesso em 13 out. 2015.
} 
Com efeito, o papa Francisco não economiza na manifestação do afeto para atrair as pessoas. Beijos, afagos e carinhos compõem de modo enfático a sua linguagem que sensibiliza de modo particular a juventude: "E tenham certeza de que meu coração os abraça a todos, com afeto universal". ${ }^{17}$ Ele investe fortemente na personalização da relação, transmitindo ao seu público uma espécie de valorização face a face, estilo adotado também pelos neopentecostais. "A todos y a cada uno, un abrazo afectuoso en Jesús y con Jesús."18 Sem dúvida, essa é uma narrativa que possui forte capacidade de atração da juventude por trazer pessoalidade, aproximação e afeto.

À medida que se destitui da realeza do poder papal e assume um modo de estar na sociedade marcado por um estilo austero, afirmando-se como alguém próximo às pessoas, o papa Francisco catalisa o interessante efeito de atração da simpatia dos fiéis em um momento em que as igrejas neopentecostais estimulam a participação emocional e afetiva das pessoas. Aos jovens argentinos, ele afirmou: "Obrigado por rezarem por mim! Isto lhes peço de coração. Preciso. Eu preciso de suas orações; tenho tanta necessidade!”’19

A partir dos discursos do papa na JMJ, fica claro que a igreja continuará investindo no aspecto missionário mais ostensivo para assegurar a sua permanência na sociedade, incrementar as taxas de adesão e fortalecer aspectos primários da fé cristã, como a evangelização e a conversão. Nesse sentido, parece haver um remodelamento do que em décadas anteriores foi compreendido como um caminho de mudanças socioestruturais a partir do engajamento social dos cristãos e da experiência de fé diretamente relacionada com a atuação em prol da justiça social. Remodelamento? Acomodação? Conciliação? Como pode ser pensada a orientação papal aos jovens no que se refere às clássicas orientações pastorais da igreja latino-americana?

17 Disponível em: http://br.radiovaticana.va/news/2017/07/25/papaemvarginhaquebompoderestarcomvo c\%C3\%AAsaqui!/1326923. Acesso em 25 jul. 2017.

18 Festa de Acolhida dos Jovens - Saudações e Homilia. Praia de Copacabana. Rio de Janeiro, 25/07/2013. Disponível em: https://w2.vatican.va/content/francesco/pt/speeches/2013/ july/documents/papa-francesco_20130725_gmg-giovani-rio.pdf. Acesso em 15 de outubro de 2013. Em visita posterior ao México, já em 2016, o papa usou a palavra "carinhoterapia" (cariñoterapia) ao referir-se à atitude necessária dos profissionais da saúde ao cuidar de crianças enfermas no Hospital pediátrico Federico Gomez. Veja em: http://www. amerindiaenlared.org/biblioteca/8429/la-carinoterapia-receta-del-papa-una-caricia-ayudatanto-a-recuperarse. Acesso em 20 fev. 2016.

19 Disponível em: http://www.veritatis.com.br/4-encontro-com-os-jovens-peregrinos-provindos-da-argentina/ Acesso em 13 nov. 2014. 
O discurso do papa Francisco sobre justiça social está em consonância com os documentos oficiais da igreja que ele recupera com habilidade. Não há, portanto, em suas narrativas, uma grande novidade em termos de conteúdo, mas sim em termos de capacidade discursiva, de inovação e sutileza no tratamento de temas como a homossexualidade e o lugar das mulheres na igreja. Sua abordagem é essencialmente pastoral e afetiva, com menos ênfase em temas institucionais polêmicos, como a doutrina moral, que geralmente são fontes de contestação e crítica.

Dotado de carisma, no sentido weberiano já explicitado, Francisco insiste no uso de uma linguagem metafórica, de fácil compreensão e apta em interagir com aspectos culturais conhecidos - o treinamento do jogador no campo - a imagem do campo como espaço de treinamento, "que sejam atletas de Cristo".

O campo como lugar de treinamento. Jesus nos pede que o sigamos por toda a vida, pede que sejamos seus discípulos, que "joguemos no seu time". Acho que a maioria de vocês ama os esportes. E aqui no Brasil, como em outros países, o futebol é uma paixão nacional. Ora bem, o que faz um jogador quando é convocado para jogar em um time? Deve treinar, e muito! [...] Queridos jovens, que vocês sejam verdadeiros "atletas de Cristo!"

Sua popularidade o fez ser eleito por duas revistas norte-americanas ${ }^{21}$ como o personagem do ano e uma pesquisa realizada após seis meses do papado entre católicos norte-americanos ${ }^{22}$ demonstrou bom nível de credibilidade - 58\% - que ele alcançou junto a um público mais geral. Surpreendentemente, na América protestante o índice de aceitação ao papa atingiu a casa dos 65\% de norte-americanos, de modo particular após sua visita ao país, em outubro de 2015.

Por sua vez, embora a maioria da população latino-americana tenha uma percepção positiva do papa Francisco, há interessantes nuanças a se considerar

20 Discurso feito na Vigília que reuniu aproximadamente três mil pessoas. Disponível em: https:/ / pt.zenit.org/articles/voces-sao-o-campo-da-fe-voces-sao-os-atletas-de-cristo/ Acesso em 19 dez. 2014.

21 TIME MAGAZINE. Nova Iorque (2013). Disponível em: http://poy.time. com/2013/12/11/person-of-the-year-pope-francis-the-peoples-pope/; ROLLING STONE. São Francisco (2014). Disponível em:

http:/ / www.rollingstone.com/culture/news/pope-francis-the-times-they-are-a-changin-20140128. Acesso em: 20 jan. 2014.

22 PEW RESEARCH CENTER. Washington (2013). Disponível em: http://www.pewforum. org/2013/09/12/six-months-into-Papacy-large-majority-of-catholics-continue-to-expressfavorable-view-of-pope-francis/. Acesso em 28 jan. 2014. 
quando se analisam os diferentes grupos de católicos. Atendo-nos somente ao Brasil, enquanto 92\% dos atuais católicos admiram o papa Francisco, entre os ex-católicos aproximadamente a metade - 51\% - apresentou uma visão otimista a seu respeito. A principal afirmação desses últimos por ocasião da pesquisa, cujos dados foram coletados em 2013, é de que ainda seria cedo para avaliar o chefe atual da Igreja Católica. ${ }^{23}$

A partir dessa perspectiva, a popularidade do papa Francisco necessita de permanente contextualização, considerando-se os diferentes atores, países e públicos para os quais dirige suas mensagens e gestos. Sua capacidade de sensibilizar a juventude para as propostas cristãs não representa, necessariamente, mudanças radicais em termos de doutrina moral da igreja, ou alterações substantivas em temas candentes, como ordenação de mulheres e celibato. Entretanto, a se levar em conta a sua extrema capacidade de sensibilização e seu carisma, esses temas parecem minimizados pelo grande público que, em geral, aponta o Vaticano ou a cúria romana como contrários às mudanças que, eventualmente, esse papa desejaria realizar.

Neste momento de renovação simbólica do papado, a JMJ ganha expressividade e mobiliza jovens religiosos de diferentes países que, atraídos pelo carisma de Francisco, buscam com ele uma identificação e legitimidade para seu modo de inserção na sociedade e na igreja, especialmente latino-americana. Isso fica claro na carta que lhe foi endereçada por jovens mexicanos, em 2016:

Somente queremos te dizer obrigado por renovar nossa Igreja, por optar pela Igreja dos pobres, por caminhar com o povo porque por um momento a Igreja se esqueceu do compromisso social que outros, ainda que não cristãos, têm retomado. ${ }^{24}$

\section{Percepções de jovens nas jornadas - crenças, práticas re- ligiosas e representações sobre o Papa Francisco}

Nesta sessão, apresentamos análises de entrevistas exploratórias com jovens participantes da JMJ, no Rio de Janeiro. Cerca de 50\% das entrevistas

23 PEW RESEARCH CENTER. Washington (2014). Disponível em: http://www.pewforum. org/2014/11/13/chapter-9-views-of-pope-francis-and-the-catholic-church/. Acesso em 20 fev. 2016.

24 Carta dos jovens de CEBs de San Cristobal de las Casas no México, fevereiro de 2016. Disponível em: http://www.amerindiaenlared.org/noticia/631/las-comunidades-eclesialesde-base-de-san-cristobal-de-las-casas--chiapas-al-papa-francisco/. Acesso em 20 fev. 2016. Tradução da autora. 
foram realizadas após o evento em função da intensa programação da JMJ, o que implicou menor tempo disponível dos jovens. Foi usada a técnica bola de neve ${ }^{25}$ (BIERNARCKI, P; WALDORF, D. 1981) para encontrar os jovens que se disponibilizaram a ser entrevistados. Analisamos percepções sobre o papa e a experiência religiosa de 27 rapazes e 20 moças, num esforço complementar a outras pesquisas em andamento, de natureza quantitativa, ${ }^{26}$ com as quais pretendemos dialogar em momento oportuno. Sendo assim, os dados falam desse universo específico, não permitindo generalizações, mas levantando questões para interlocuções futuras.

Entre nossos informantes, apenas um rapaz era evangélico, e os demais católicos. Quanto às mães dos jovens informantes, vimos que a maioria delas é católica, mas duas moças declararam que suas respectivas mães são sem religião. Outros dois jovens - uma moça e um rapaz - possuem mães evangélicas. Os pais de um jovem católico são umbandistas. Essa descrição oferece um perfil da composição religiosa familiar dos entrevistados e revela a heterogeneidade desse universo. Além disso, recoloca em cena a categoria sem religião que sinalizamos na contextualização deste texto ao apresentarmos os dados do Estado do Rio de Janeiro. ${ }^{27}$

Um universo mais plural em termos de identidade religiosa ou arreligiosa apareceu de modo mais acentuado entre os pais dos informantes, pois quatro entrevistados declararam que seus respectivos pais são sem religião; o pai de um rapaz é ateu; dois pais seriam espíritas. Evangélico não determinado, presbiteriano e budista configuram-se como identidades religiosas dos pais de três jovens católicos, respectivamente.

Destaque-se que o perfil familiar já descrito dos católicos informantes sugere que as mães teriam maior capacidade de transmissão religiosa quando comparadas aos pais ou, em outra direção, que os pais não exercem posição determinante na formação da identidade religiosa juvenil. Essa hipótese vem

25 A técnica bola de neve, também conhecida como snowball, consiste em iniciar a pesquisa a partir de um informante com as características e perfil desejado pelo pesquisador. Tal informante indica outras pessoas de sua relação e assim sucessivamente. Trata-se, portanto, de uma amostra não probabilística que utiliza cadeias de referência.

26 Este trabalho está em consonância com pesquisa coordenada por Cecília Mariz e Paulo Gracino (2013) sobre religião no espaço público em que se analisam diferentes manifestações públicas da religião incluindo a JMJ.

27 O objetivo deste artigo não é discutir a presença dos sem religião, mas pesquisas estão sendo desenvolvidas nessa direção junto a jovens residentes no Estado do Rio de Janeiro (FERNANDES, 2015). 
sendo trabalhada em estudos atuais (FERNANDES, 2015a) mais detidamente, que sinalizam para a necessidade de investimento em estudos sobre transmissão religiosa intergeracional. Entre os jovens que afirmaram adesão ao catolicismo, verificou-se mobilidade religiosa nos segmentos feminino e masculino. Boa parte das moças não nasceu em berço católico, tendo, portanto, mães ou pais evangélicos ou ainda uma ausência de identidade religiosa dos respectivos pais, considerados por elas como sendo sem religião. Sublinhe-se ainda que o tempo de adesão ao catolicismo dessas moças varia entre seis a dezesseis anos. Entre os rapazes, umbanda e ateísmo configuram-se como identidades religiosas que precederam a católica. Em alguns casos, a família era agnóstica ou sem religião. Sendo assim, o tempo de adesão ao catolicismo para esses rapazes varia entre cinco a dezesseis anos, tendo eles experimentado, portanto, a mobilidade religiosa apontada em vários estudos sobre o campo religioso brasileiro (FERNANDES, 2006; ALMEIDA; MONTERO, 2001).

Visando informar ao leitor sobre o perfil de nossos entrevistados, temos que mais da metade dos jovens estava cursando nível superior e a maioria declarou-se preta ou parda, embora brancos e autodeclarados caucasianos também componham o conjunto de informantes. Esses dados desenham um retrato situado, mas não pretendem sugerir ser esse o perfil dos jovens católicos que participaram da JMJ.

Boa parte de nossos informantes manifestou conformidade aos ensinamentos da igreja, tendo sido a expressão "doutrina da igreja" por eles acionada várias vezes, o que pode sugerir assimilação das orientações mais difundidas pela Renovação Carismática. A tendência parece se confirmar quando esses jovens indicam os elementos que mais admiram na Igreja Católica: eucaristia, os sacramentos e a tradição. É importante sublinhar que alguns contestaram o que denominaram "posturas conservadoras" da igreja e ainda uma jovem oriunda de família evangélica ressalvou: "apesar de ser católica, não creio em santos". Claramente, o ambiente familiar anterior pode orientar a nova conduta religiosa configurada com adesão parcial a elementos do sistema de crenças da nova religião. Essa situação ocorre também com jovens que se convertem ao catolicismo em outros países, como nos Estados Unidos (FERNANDES, 2014).

Importa sublinhar que as representações dos jovens acerca do papa Francisco não são absolutamente consensuais, podendo revelar, por um lado, preocupações com mudanças radicais na tradição, e por outro, a admiração ao estilo do papa por eles considerado como "humilde" e "solidário". A "bonda- 
de" também foi recorrentemente indicada pelos jovens como uma virtude do papa argentino. Alguns deles preferiram assumir uma posição mais cautelosa na avaliação do chefe da igreja, uma vez que na ocasião das entrevistas ${ }^{28}$ sua eleição era recente. Assim, se o papa Francisco é visto como "exemplo de "simplicidade" e "humildade" a ser seguido, algumas ponderações e hesitações estavam presentes nas narrativas de jovens participantes da JMJ no Rio.

Um rapaz de 19 anos de idade, cuja mãe é evangélica, embora manifestando relativa simpatia ao papa pelo que considerou ser sua "abertura com os fiéis", declarou que "ele ter mudado algumas coisas características do papa me incomoda um pouco". Foi ainda interessante notar a avaliação de uma jovem adulta (30 anos de idade) em relação ao papa. Ainda que proveniente de família católica, a moça abandonou o catolicismo a partir do ingresso na faculdade de engenharia, tornando-se agnóstica. Ao entrar em contato com os grupos de oração da RCC, retornou ao catolicismo e passou a assumir um discurso de valorização dos sacramentos, Maria e outros elementos que demarcam a adesão institucional. No entanto, declarou não nutrir simpatia pelo papa Francisco que, em sua visão, pretende mudar a igreja: "Ele é o papa, mas não gosto dele. Preferia Bento XVI que buscava conservar a igreja em suas bases, mas Francisco quer mudar a igreja".

Por sua vez, vários jovens mostraram-se entusiastas do então novo papa argentino, ressaltando características como "lindo", "carismático", "caridoso". Um rapaz de 19 anos de idade, cujo pai é ateu e a mãe católica, afirmou em relação a Francisco: "Uma pessoa sábia, honesta e de bom coração, que tem todo meu respeito e carinho".

As entrevistas permitem considerar a hipótese de haver um perfil heterogêneo entre os jovens católicos presentes na JMJ do Rio de Janeiro. As identidades católicas juvenis são formadas a partir de um conjunto de representações que muitas vezes são originárias da experiência religiosa anterior, e por esse motivo podem tender a maior ou menor adesão a elementos da tradição católica. No universo juvenil heterogêneo de católicos, há os que primam por mudanças e os que as temem, revelando interessantes posições em um segmento que seria, aparentemente, integralmente favorável ao papa argentino.

A pesquisa de Luciana Gonzalez (2016) constatou certos conflitos que os jovens católicos viviam quanto à conciliação entre crenças e práticas religiosas, embora o foco da autora tenha sido a estrutura do evento e o perfil de

28 Entrevistas realizadas em 2013, ano de eleição de Jorge Bergoglio. 
voluntários e peregrinos que nele estiveram. Do mesmo modo, a pesquisa de Paulo Gracino Jr. e Cecília Mariz (2013) ${ }^{29}$ permitirá ponderar e complementar algumas das interpretações aqui realizadas sobre as representações de jovens católicos participantes do evento.

\section{Os jovens e a igreja na mídia - expansão e características ${ }^{30}$}

A JMJ viabilizou ainda a expansão do segmento juvenil nas redes sociais e veículos midiáticos, demarcando para o catolicismo em declínio uma fase mais interativa e potencialmente catalisadora de novos adeptos em um dos segmentos mais arredios à mensagem católica no mundo: a juventude.

A partir de vários documentos ${ }^{31}$ da Igreja Católica, identifica-se que o eixo central das preocupações institucionais está referido à crise que ela atravessa diante de um mundo que relativiza a força de vínculos e que experimenta mudanças importantes no que diz respeito aos valores culturais. Incluem-se aí as políticas de mobilidade humana e as novas tecnologias na era global. Essas rápidas transformações produzem efeito imediato nas novas gerações imersas em um tempo que se configura virtualmente real e que estão assoberbadas pela infinidade de escolhas que precisam fazer, especialmente na fase juvenil.

Como indicou Pierre Bourdieu (1983), uma única palavra não traduz a juventude e, mesmo dentro da Igreja Católica, há muitas possibilidades de concepções e práticas de experimentação do catolicismo por jovens de diferentes correntes. Vários estudos têm sublinhado o pluralismo, e até mesmo o hibridismo católico, fato que, por sua vez, é tido pela Igreja Católica como um tempo de "águas agitadas". 32

A igreja vem tentando apropriar-se das novas tecnologias e modos comunicacionais favorecidos por tais meios como uma forma de lidar com a agitação das marés e é exatamente a juventude que demonstra habilidade no manejo dessa linguagem. Como produtora cultural dotada de uma concepção específica de homem e sociedade (DELLA CAVA; MONTERO, 1991) a igreja

\footnotetext{
29 Até a redação deste texto a pesquisa de Gracino Jr. e Mariz estava em fase de análise.

30 Agradeço especialmente à aluna de Iniciação Científica da UFRRJ Olga Chiapim (FAPERJ) pelo intenso levantamento e relatório de pesquisa que favoreceu a elaboração desta parte do texto.

31 Ver os estudos da CNBB disponíveis na página da organização: www.cnbb.net.br, além das encíclicas papais. Acesso em 10 abr. 2014.

32 Expressão usada por Bento XVI em seu último discurso como Papa. Disponível em: http://g1.globo.com/mundo/renuncia-sucessao-Papa-bento-xvi/noticia/2013/02/na-ultima-audiencia-bento-xvi-diz-que-Papado-teve-aguas-agitadas.html. Acesso em 12 abr. 2013.
} 
privilegia a disseminação de valores morais e religiosos e se esforça em formar os segmentos juvenis a partir deles. ${ }^{33}$

Nas décadas de 1960 a 1990, a expansão dos meios de comunicação no Brasil e a relação da igreja frente a tal cenário foram analisadas a partir da gramática: inserção ou afastamento institucional da mídia secular, constituída como um espaço profano em que o sagrado seria subtraído. Há um conjunto de documentos institucionais que demonstram o processo reflexivo da Igreja Católica frente à questão dos meios de comunicação, especialmente a partir da década de 1980 (CNBB, 1982; 1994, 1997, 1997ª).

$\mathrm{Na}$ atualidade, evidenciam-se os esforços institucionais visando entrar em consonância com as novas tecnologias de comunicação, elemento central nesta fase da modernização brasileira, e que posiciona os jov6ens como atores principais, independentemente de sua origem socioeconômica. Uma dessas iniciativas foi a implementação, em 2011, do I Seminário de Comunicação para os Bispos do Brasil onde os bispos ouviram palestras acerca de teorias da comunicação, cibercultura e crimes na internet, entre outros subtemas.

Destarte, a modernização acaba por gerar tensões relacionadas aos limites de inserção da igreja na mídia. Atualmente, as declarações papais têm enfatizado a importância de estreitamento com a internet e as novas tecnologias comunicacionais, iniciativas essas iniciadas pelo papa Bento XVI. Desse modo, tanto o papa Francisco como seminaristas, membros do clero e religiosas utilizam Twitter e outras redes sociais. E, por ocasião das Jornadas, essa prática facilitou a expansão do evento e catalisou a motivação juvenil. ${ }^{34}$ Sendo assim, um considerável esforço tem sido feito para atingir novos adeptos fazendo uso desses meios.

Com efeito, durante muito tempo, em se tratando dos meios televisivo e radiofônico, a Igreja Católica esteve relativamente aquém em relação aos

33 A editora da CNBB lançou a coleção "Aos jovens com afeto" que em cada volume aborda temas relacionados à afetividade e sexualidade juvenil. Disponível em: https://www. edicoescnbb.com.br/aos-jovens-com-afeto-vol-1-vida-e-sexualidade.html. Acesso em 12 abr. 2016.

34 Não há dados quantitativos a respeito do número de religiosos que utilizam a internet para transmissão de mensagens religiosas. Entretanto, para além da atuação de padres cantores como Marcelo Rossi e Fábio de Melo, entre outros, na mídia, uma rápida pesquisa no YouTube retorna com dezenas de vídeos em que padres, seminaristas e outros religiosos divulgam mensagens cujo conteúdo religioso predomina. No que se refere ao uso da mídia por parte de atores religiosos, caberia uma pesquisa específica. O trabalho de Luís Martino (2017) oferece uma importante contribuição para pensar a relação entre mídia e religião. Especificamente sobre padres midiáticos ver Fernandes, 2005; 2010 e Carranza, 2011. 
seus "concorrentes na fé", tentando afastar-se da lógica de mercado que a instituição compreendia estar presente nesses meios. Por sua vez, Della Cava e Montero (1986) alertaram para o fato de que o conceito "lucro" não pode ser usado para analisar a produção de mensagens religiosas da mesma forma que é empregado para se analisar o cálculo de empresas culturais:

Ao contrário da mensagem secular onde ele [receptor da mensagem] é apenas um mediador, um instrumento para o retorno econômico, a mensagem religiosa faz da manutenção do público o seu fim imediato. Essa diferença de alvos visados na produção de mensagens evidencia o fato de que há diferenças fundamentais entre a televisão que se organiza enquanto empresa e o uso da televisão para fins de conversão. Embora possam, em alguns casos, assumir alguns aspectos da organização racional das empresas, os cultos religiosos não respondem à mesma racionalidade. Assim, apesar de as mensagens religiosas serem muitas vezes definidas como 'mercadoria', essa definição só pode ser considerada enquanto uma imagem metafórica, já que, ao contrário dos produtos culturais seculares, não é a correlação investimento/lucro que está na base de sua produção (mas sim a necessidade de 'salvar almas') (DELLA CAVA; MONTERO; 1991).

Atualmente, a igreja persiste no intuito de legitimar seu discurso por meio de meios de comunicação e o que tem sido chamado de cultura midiática (FERNANDES, 2015), e isso vem ocorrendo com intensidade gradual. Embora o ambiente virtual seja distinto do ambiente radiofônico e televisivo, os conflitos em relação à modernidade apresentam uma face similar. $\mathrm{O}$ evento bienal organizado pela Conferência Nacional dos Bispos do Brasil - CNBB com outras organizações católicas, denominado "Mutirão da Comunicação", expressa esse esforço da instituição em apropriar-se das novas linguagens e tecnologias da era virtual. A primeira edição aconteceu em 1998, em Minas Gerais, sob o tema - Solidariedade, Ética e Cidadania, e o tema da ética nas comunicações volta a aparecer na edição do evento em 2015.

Nota-se ainda um interesse relacionado com a imagem da igreja, a partir dos diferentes ambientes comunicacionais. Por ocasião da $35^{\mathrm{a}}$. Assembleia Geral dos Bispos do Brasil, em seu documento conclusivo, a CNBB orienta sobre os cuidados para com a imagem da igreja. Nesse documento, lançado em 1997, já se observa que havia interesse e preocupação por parte dos bispos quanto ao uso das novas tecnologias. Além disso, o texto oferece um conjunto de orientações para o corpo institucional, no sentido de qualificar a imagem da igreja nos diferentes meios. 
Cuidar da imagem pública da Igreja uma vez que sua aceitação e reconhecimento por parte dos vários segmentos da sociedade dependem da forma como se apresenta e da credibilidade que alcança junto ao público. Fazer pesquisas de opinião sobre a imagem pública da Igreja, dirigindo-se também aos que estão fora da Instituição (CNBB, 1997).

Por meio de uma pesquisa realizada em artigos, sites de natureza informativa e sites criados e monitorados pela própria igreja, ${ }^{35}$ observamos preocupações como: a questão contínua da preservação da família, o compromisso com a dignidade humana e a autenticidade nas relações. Esses seriam conteúdos recorrentes presentes nos canais católicos. No processo de integração da igreja com a cultura midiática, alguns elementos são incluídos e outros excluídos pelos agentes religiosos e pelos jovens. A compreensão dos complexos caminhos pelos quais esses significados são construídos passa pela caracterização dos meios e pelos valores e interesses que os agentes possuem (HODKINSON, 2010).

Como vimos, a Igreja Católica tem disseminado o discurso que demanda aos seus adeptos um posicionamento que preserve os chamados "valores cristãos" no que se refere ao uso da internet, ressaltando que devem utilizá-la de maneira construtiva. Dessa forma, o que a instituição rejeita, segundo esse discurso apresentado, seria o chamado "uso superficial" do meio. Tal tendência de rejeição à "superficialidade das relações" em ambiente virtual é bastante discutida também entre psicólogos e educadores e o segmento focado é, na maioria das vezes, a juventude (PORTO, 2006).

A JMJ visa mobilizar e reunir o público juvenil numa estratégia bem definida da Igreja Católica para provocar a participação ativa desse segmento. $\mathrm{Na}$ primeira Encíclica do papa Francisco, intitulada Lumen Fidei (A luz da fé), o papa afirma:

Todos vimos como, nas Jornadas Mundiais da Juventude, os jovens mostram a alegria da fé, o compromisso de viver uma fé cada vez mais sólida e generosa. Os jovens têm o desejo de uma vida grande; o encontro com Cristo, o deixar-se conquistar e guiar pelo seu amor alarga o horizonte da existência, dá-lhe uma esperança firme que não desilude. ${ }^{36}$

35 Confira, no final, a lista de sites pesquisados. A pesquisa foi realizada no decorrer dos anos de 2013 e 2014.

36 Carta encíclica Lumen Fidei, p. 69. Disponível em: http://w2.vatican.va/content/ $\mathrm{dam} /$ francesco/pdf/encyclicals/documents/papa-francesco_20130629_enciclica-lumenfidei_po.pdf Acesso em : 21 jul. 2017. 
Entre as diferentes estratégias de sensibilização do segmento juvenil, o uso da internet tem se destacado. Constata-se a existência de uma infinidade de canais de comunicação on-line criados por jovens com o apoio de párocos e outros religiosos.

Um exemplo é o caso de jovens atuantes em uma paróquia de Niterói, RJ. Eles contaram com a ajuda do pároco local para produzir uma sala de aula virtual, com vídeo e bate-papo, cujo intuito é ensinar o catecismo católico e conquistar novos membros. O site YouCat é uma iniciativa em vários países, pois surgiu justamente com a necessidade de instruir os jovens de acordo com os ensinamentos católicos. Antes lançado como livro de teor catequético, agora tem sua página na internet e está presente em redes sociais como o YouTube, Facebook, Twitter e no Blogspot.

Cabe destacar que o livro virtual YouCat foi lançado em agosto de 2011, na Jornada Mundial da Juventude, em Madri, e no prefácio contém uma mensagem do papa Bento XVI em que o apelo ao estudo do catecismo é veemente:

Estudai o catecismo com paixão e perseverança! Para isso, sacrificai tempo! Estudai-o no silêncio do vosso quarto; lede-o enquanto casal se estiverdes a namorar, formai grupos de estudo e nas redes sociais, partilhai-o entre vós na internet! Permanecei deste modo num diálogo sobre a vossa fé ${ }^{37}$

O portal Jovens Conectados ${ }^{38}$ é outra iniciativa que dá visibilidade midiática às ações institucionais, mais especificamente promovidas pela Comissão para a Juventude da CNBB. No site, há notícias das diversas atividades realizadas pelos jovens ou para jovens católicos, incluindo-se atualizações sobre as Jornadas Mundiais da Juventude, o DNJ - Dia Nacional da Juventude, além de subsídios e materiais institucionais visando a formação do jovem católico.

Durante o monitoramento das atividades juvenis por meio da internet, no período da JMJ, localizamos o site "Jovens Católicos". ${ }^{39}$ No endereço virtual, realizou-se uma campanha para o acolhimento de peregrinos na JMJ, além de um vídeo do YouTube com o relato de jovens católicos peregrinos. Em geral,

37 Disponível em: http://www.youcat.org.br/o-prefacio-do-papa-bento-xvi/. Acesso em 21 mar. 2015.

38 JOVENS CONECTADOS. Instituto debaterá questões da juventude. Rio de Janeiro (2013). Disponível em: http://jovensconectados.org.br/instituto-debatera-questoes-da-juventude. html. Acesso em 12 mar. 2016.

39 JOVENS CATÓLICOS. Rio de Janeiro (2015). Disponível em: http://jovenscatolicos. com.br/. Acesso em 3 jan. 2016. 
destacam-se páginas como: NEWS.VA, que transmite diariamente notícias sobre o Vaticano; o canal oficial da JMJ no YouTube; o portal Católicos Online; o site Pope To You, com versão em português e em outros cinco idiomas; além de vários perfis de religiosos em redes sociais e casos de paróquias que transmitem missas on-line. A própria JMJ contou com a transmissão on-line em uma parceria com a Google, através do YouTube Live.

A organização da JMJ defende a existência de um conjunto de legados, entre os quais destaca-se a criação de um Polo de Atenção Integral à Saúde Mental (PAI), o Instituto Juventude e projeto Vozes Católicas. ${ }^{40} \mathrm{O}$ último originou-se na Inglaterra, em 2010, por iniciativa de um especialista em comunicação vinculado ao grupo Opus Dei e está presente em cerca de quinze países. No Brasil, o projeto vem sendo implantado com o objetivo de dar suporte às necessidades da imprensa acerca de temas relacionados à Igreja Católica, principalmente os mais controversos. Os portadores das notícias são leigos formados pelos organizadores, e no Rio de Janeiro, a iniciativa recebeu total apoio do arcebispo Orani Tempesta.

A Igreja Católica tem, portanto, um conjunto de ações que busca legitimar seus discursos através dos meios de comunicação, tornando mais robusta a entrada institucional nos novos dispositivos midiáticos. Desse modo, a instituição tem seguido a pista iniciada por João Paulo II, e corroborada por Bento XVI. Entretanto, tem sido o papa Francisco o mais hábil comunicador na era virtual católica, disseminando uma cultura de afeto e personalização da fé que pode vir a lograr sucesso, mas não necessariamente a revolucionar dogmas e doutrinas dessa instituição milenar. Que impactos suas narrativas podem provocar para o catolicismo vivido por novas gerações?

\section{O futuro do catolicismo em rota de mudança? aportes finais}

Vimos que a temática juventude católica no Brasil está intimamente relacionada com o panorama religioso atual e as tendências nesse campo, marcadas, sobretudo, pelo potencial de segmentos juvenis como agentes de mudança do cenário católico de declínio de adeptos.

Cabe sublinhar que a juventude católica apresenta, assim como qualquer grupo, marcas definidas pela geração em si. Uma das marcas geracionais que tocam diretamente os segmentos juvenis é o que pode ser denominado como

40 ZENIT. Brasil: O Vozes Católicas foi um dos legados oficiais da JMJ Rio 2013. Taubaté (2014). Disponível em: https://pt.zenit.org/articles/brasil-o-vozes-catolicas-foi-um-dos-legados -oficiais-da-jmj-rio-2013/. Acesso em: 20 nov. 2014. 
cultura midiática, compreendida como linguagem, modos de expressão e conjuntos de ideias, comportamentos e linguagens que integram a comunicação mediada por novas tecnologias e por veículos tradicionais de comunicação. No entanto, não há que se compreender a assimilação da cultura midiática pelos jovens como uma evidência de homogeneização da categoria juventude (FERNANDES, 2009; 2015), visto que os jovens vivem realidades diversas sob o ponto de vista social, cultural, econômico, político e educacional.

A Igreja Católica vem tentando chamar a atenção dos jovens para questões como "solidariedade", "comunhão" e "testemunho de fé". Atitudes essas que, segundo suas lideranças, devem ser preservadas e disseminadas também no mundo virtual e que vêm caracterizando o tom dos discursos papais remetidos à juventude. Tendo em mente essa disposição, agentes religiosos convidam os fiéis para uma postura mais evangelizadora em todos os ambientes de sociabilidade, e alguns dos organizadores da JMJ defendem ser possível perpetuar um sentimento no qual a juventude católica se mantenha engajada para além da Jornada Mundial da Juventude e da visita do papa, ${ }^{41}$ o que parece vir acontecendo em diversas comunidades católicas no país, merecendo estudos seriados.

Mas a unanimidade acerca das perspectivas do catolicismo a partir do pontificado de Francisco não pode ser dada como uma realidade acabada. Em pesquisa com jovens participantes da JMJ, no Rio de Janeiro, evidenciou-se que, apesar das narrativas do papa Francisco produzirem uma reação majoritariamente positiva, elegendo-se sua simplicidade e desejo de renovação da Igreja em diferentes aspectos como destaques de sua atuação, um pequeno grupo demonstrou incômodo com mudanças que poderiam vir a ser incrementadas por Francisco.

Esses jovens dissonantes da maioria criticaram a quebra de tradições ou expressaram preocupações com a condução que o papa Francisco dará à igreja. Trajetórias marcadas por pertencimentos a religiões anteriores ou a uma identidade religiosa fora do cristianismo conformam o perfil dos jovens que apresentaram incômodos frente às narrativas ou à figura do papa Francisco que, à época das entrevistas, acabara de ser eleito. Curiosamente, dois dos jovens incomodados com o então novo papa eram novos católicos, tendo migrado do protestantismo para o catolicismo; uma moça, que retornara ao

41 PORTAL PUC RIO DIGITAL. Dom Orani: solidariedade deve se perpetuar. Rio de Janeiro (2010). Disponível em: http://puc-riodigital.com.puc-rio.br/Jornal/Campus/Dom-Orani\%3A-solidariedade-deve-se-perpetuar-6503.html. Acesso em 12 de jan. 2013. 
catolicismo havia cinco anos, sendo anteriormente agnóstica, e um dos jovens que demonstraram rejeição ao papa Francisco, relataram que o que mais gostam em sua igreja é a tradição, o latim e o papado. Para o rapaz, portanto, inovações no papado soam ameaçadoras à instituição.

A existência desse perfil, que em um primeiro momento seria analiticamente tratado como conservador - considerando-se jovens católicos -, demanda maior investimento no sentido de compreender os elementos presentes na cosmovisão juvenil que demarcariam aspectos da tradição, contrariando o que se poderia apresentar como uma característica do segmento. A saber: o impulso para a mudança. Por sua vez, não nos parece apropriado afirmar simplesmente haver um crescimento do chamado "conservadorismo" juvenil em função de posicionamentos dissonantes da maioria acerca do papa Francisco. Assim, boa parte dos jovens católicos entrevistados afirmou crer na mudança da sociedade a partir de suas ações, sinalizando tendências distintas que não poderíamos, a priori, classificar como progressistas ou conservadoras: Eles dizem que podem mudar o mundo a partir da oração; ou das manifestações públicas em defesa de direitos; ou reforçando a tradição; ou lutando contra a "opressão do sistema", ou mudando a si mesmos. Mas o voto também emergiu em algumas narrativas como um mecanismo de mudança importante das sociedades. Ao que parece, a chave conservadorismo versus progressismo não seria apropriada para a análise do segmento e ler o "conservadorismo" de maneira precisa representaria compreender suas nuanças e configurações a partir das disposições juvenis.

A imagem do papa Francisco para a maioria foi associada à simplicidade, humildade e renovação, denotando assimilação das narrativas e estilo do papa argentino por parte de segmentos juvenis católicos. Uma jovem de 20 anos de idade afirmou enfática: "Ele é um ser humano simples, humilde e simpático. Espero que seja verdadeiro". Essa mesma jovem declarou ser favorável aos protestos e manifestações, pois acredita que os "cidadãos devem manifestar-se por um mundo melhor". Muitos dos jovens que opinaram sobre os protestos ressaltaram, entretanto, o aspecto da não violência, sendo contrários ao "vandalismo" e "depredações", demonstrando consonância com a orientação do papa a respeito das manifestações políticas no país, por ocasião das Jornadas.

Considera-se ser, portanto, mais profícuo analisar as nuanças das mudanças de paradigmas que têm afetado de algum modo o comportamento juvenil - especialmente o católico - em razão do caso em análise, sem que o selo do conservadorismo venha a ser a principal chave analítica. Cabe levar 
em conta que as gerações têm suas especificidades e devem ser compreendidas nelas mesmas evidentemente contando com o instrumental teórico e empírico necessário a determinadas interpretações.

Importa, por fim, analisar em profundidade as inter-relações entre discurso oficial da Igreja, uso de linguagem informal e personalizada na transmissão da fét ${ }^{42}$ e a forte aderência e aceitação social desse estilo narrativo e vivencial proposto pelo papa argentino. Seria apropriado investir em uma análise mais rigorosa a respeito do que nos soa como uma nova cultura do afeto que parece conseguir minimizar aspectos da igreja antes duramente contestados, por exemplo, a sua doutrina moral; cultura que se expande por meio das ondas da cultura midiática e que vocaliza atores jovens simpáticos tanto a causas de ordem espiritual quanto social, sacralizando as redes sociais e "viralizando" na internet suas mensagens religiosas.

$\mathrm{Na}$ verdade, ao tocar em temas relacionados ao campo da justiça social, o papa Francisco realiza uma retomada da tradição latino-americana realizando novas sínteses narrativas para além da chave conservador versus progressista. Assumiríamos que tais sínteses estão ainda em construção. Parece claro, entretanto, que as novas linguagens e recursos virtuais e midiáticos integrarão as possíveis mudanças do catolicismo no mundo latino-americano tomado pela expansão do pentecostalismo que se diversifica ampliando o diálogo com a cultura, como se vê na impressionante conjugação entre ritmos musicais populares como o funk e ethos pentecostal capitaneados por jovens religiosos. ${ }^{43}$

Resta-nos saber se a popularidade de Francisco se converterá em números de adeptos para o catolicismo latino-americano, de modo particular, junto ao segmento juvenil que tanto tem se mostrado refratário aos discursos oficiais da Igreja Católica quanto relativamente receptivo às narrativas e perfil afetivo do papa argentino.

42 Em outra notícia vemos, inclusive, o depoimento da jovem Verônica Freire de 18 anos de idade, que será voluntária na organização do evento, afirmando que um papa argentino será capaz de estabelecer uma interação maior com os jovens brasileiros: http://noticias. bol.uol.com.br/internacional/2013/03/13/Papa-argentino-vai-nos-entender-melhor-dizjovem-brasileira.jhtm. Alguns sites destacam também que o pontífice fala português e é capaz de se comunicar em sete idiomas, inclusive o latim.

43 Confira o vídeo "Relaxa na Bíblia" em que vários jovens evangélicos contestam drogas e sexo por meio do ritmo funk. https://www.youtube.com/watch?v=8Zp3UEhThJ4. Acesso em: 20 jan. 2013. 


\section{Referências}

AGÊNCIA ECCLESIA. Igreja Católica sem medo da era digital. Lisboa, jun. 2011. Disponível em: <http://www.agencia.ecclesia.pt/cgi-bin/noticia.pl?\&id=85902> Acesso em 10 jul. 2011.

AGÊNCIA ECCLESIA. Redes sociais preparam face a face. Lisboa, mai. 2011. Disponível em: <http://www.agencia.ecclesia.pt/cgi-bin/noticia.pl?id=85902> Acesso em 10 jul. 2011.

AGÊNCIA ECCLESIA. JMJ 2013: 3,7 milhões de pessoas na Missa final da Jornada Mundial da Juventude. Rio de Janeiro, 2013. Disponível em: http://www.agencia.ecclesia. pt/noticias/vaticano/jmj-2013-37-milhoes-de-pessoas-na-missa-final-da-jornada-mundial-dajuventude/. Acesso em 12 mar. 2014.

ALMEIDA, Ronaldo; MONTERO, Paula. Trânsito religioso no Brasil. São Paulo Perspectiva, v. 15, n. 3, p. 92-100, 2001.

AMERIDIAN ENLARED. La “cariñoterapia”, receta del Papa: "Una caricia ayuda tanto a recuperarse...” Uruguai (2016). Disponível em: http://www.amerindiaenlared.org/bibliote$\mathrm{ca} / 8429 /$ la-carinoterapia-receta-del-papa-una-caricia-ayuda-tanto-a-recuperarse. Acesso em 20 fev. 2016.

AMERIDIAN ENLARED. Las Comunidades Eclesiales de Base de San Cristobal de las Casas - Chiapas, al papa Francisco. Uruguai (2016). Disponível em: http://www.amerindiaenlared. org/noticia/631/las-comunidades-eclesiales-de-base-de-san-cristobal-de-las-casas--chiapas-al-papa-francisco/. Acesso em 20 fev. 2016.

BIERNARCKI, P.; WALDORF, D. Snowball sampling-problems and techniques of chain referral sampling. Sociological Methods and Research, v. 10, n. 2, p. 141-163, nov. 1981.

BOURDIEU, P. A juventude é apenas uma palavra. In: BOURDIEU, Pierre. Questões de sociologia. Rio de Janeiro: Marco Zero, 1983.

CANÇÃO NOVA. Novas tecnologias são analisadas por bispos e comunicadores. Rio de Janeiro, jul. 2011. Disponível em: <http://noticias.cancaonova.com/noticia.php?id=282618> Acesso em 10 jul. 2011.

Entenda o que é a Jornada Mundial da Juventude. São Paulo (2016). Disponível em: https://noticias.cancaonova.com/especiais/jmj/cracovia-2016/entenda-o-que-e-a-jornadamundial-da-juventud. Acesso em 16 jul. 2017.

JMJ em Cracóvia reuniu 2,5 milhões de peregrinos, estima COL. Cracóvia (2016). Disponível em: https://noticias.cancaonova.com/especiais/jmj/cracovia-2016/coordenadorgeral-faz-balanco-da-jmj/. Acesso em 12 jul. 2017.

CARRANZA, B. 'A JMJ cristalizou a consagração da cultura gospel católica no Brasil.' IHU online. Disponível em: http://www.ihu.unisinos.br/entrevistas/522322-as-intervencoesdo-pontifice-mudaram-de-tom-da-presenca-teologica-para-o-contato-pastoral-entrevista-especialcom-brenda-carranza. Acesso em 30 ago. 2013.

Catolicismo midiático. São Paulo: Ideias e Letras, 2011.

CNBB. Liturgia de rádio e televisão. Estudos da CNBB, 33. São Paulo: Paulinas, 1982. 
Narrativas institucionais e juvenis a partir da JMJ:

emergências de afeto e cultura midiática no catolicismo

. Diretório de Comunicação e Igreja no Brasil. Documentos 99. São Paulo: Paulinas, 1994.

Pastoral da Comunicação - rumo ao novo milênio, planejamento integrado.

São Paulo: Loyola, 1997.

Igreja e Comunicação - Rumo ao novo milênio, Documento 59. São Paulo: 1997.

Disponível em: http:/ /www.cnbb.org.br/index.php?option=com_docman\&view=document\&layout $=$ default\&alias $=122-59$-igreja-e-comunicacao-rumo-ao-novo-milenio\&Itemid $=251$. Acesso em: 19 abr. 2016.

Documentos Fundamentais sobre as Jornadas Mundiais da Juventude. Brasília: Edições CNBB, 2012.

DELLA CAVA, R.; MONTERO, P. ... E o verbo se faz imagem - Igreja Católica e os Meios de Comunicação no Brasil: 1962-1989. Petrópolis: Vozes, 1991.

A Igreja Católica e os Meios de Comunicação de Massa. Religião e Sociedade, 13 (3). Rio de Janeiro: ISER, 1986.

DN PORTUGAL. Padres recrutam crentes através do Facebook. Portugal, jun. 2011. Disponível em: < http://www.agencia.ecclesia.pt/cgi-bin/noticia.pl?\&id=85902> Acesso em: 6 jul. 2015.

EDIÇÕES CNBB. Aos jovens com afeto Vol. 1 - Vida e sexualidade. Disponível em: https://www.edicoescnbb.com.br/aos-jovens-com-afeto-vol-1-vida-e-sexualidade.html. Acesso em 12 abr. 2016.

EL PAÍS. Vatileaks. Espanha. Disponível em: https://elpais.com/tag/vaticanleaks/a/. Acesso em: 20 no. 2015.

A revolução do papa Francisco completa quatro anos. Brasil (2017). Disponível em: https://brasil.elpais.com/brasil/2017/03/13/internacional/1489410017_522519.html. Acesso em 18 jun. 2017.

FAGGIOLI, M. Francisco: o primeiro papa realmente pós-Concílio. Entrevista concedida ao IHU online, maio, 2015. Disponível em: https://goo.gl/E1Bykf. Acesso em 23 jul. 2017.

FERNANDES, S. R. A. Padres cantores e a mídia - representações da identidade sacerdotal. Ciências Sociais e Religião, v. 7, n. 7, 2005. Disponível em: http://www.seer.ufrgs.br/CienciasSociaiseReligiao/article/view/2281. Acesso em 12 jul. 2017.

- (Org.). Mudança de religião no Brasil - desvendando sentidos e motivações. São Paulo: Palavra e Prece, 2006, v. 1, p. 235.

- Juventude nas Igrejas e fora delas: crenças, percepções da política e (des)vinculações. Tomo, n. 14, jan./jun. 2009, p. 99-126.

Os números de católicos no Brasil - mobilidades, experimentação e propostas não redutivistas na análise do Censo. In: TEIXEIRA, F.; MENEZES, R. Religiões em Movimento - o censo de 2010. Petrópolis, RJ: 2013, p. 111-126.

VASQUEZ, M. Is New Pope's Take on the Poor All That New? Religion Dispatches. Estados Unidos, 2013. Disponível em: http://religiondispatches.org/is-new-popes-take-onthe-poor-all-that-new/. Acesso em: 25 jul. 2013. 
Religiosidades, trânsitos e permanências no século XXI - particularidades das novas gerações. In: PANASIEWICZ, R.; VITÓRIO, J. (Orgs.). Espiritualidades e dinâmicas sociais. São Paulo: Paulinas, 2014, p. 81-109.

. Mosaicos contemporâneos: cultura religiosa e midiática entre os jovens. In: BOEING, A. (Org.). Trilhas do saber, $\mathbf{n}^{\mathbf{0}}$ 1. Brasília: Edebê, 2015, p. 13-26.

. Vínculo e (im) permanências - religião e política em segmentos juvenis. Projeto de pesquisa em andamento. FAPERJ, 2015. GERTH, H. H.; MILLS, W. (Org.). Max Weber: Ensaios de Sociologia. Rio de Janeiro: Guanabara Koogan (1946) 1982.

GLOBO. Na última audiência, Bento XVI diz que papado teve 'águas agitadas'. São Paulo (2013). Disponível em: http://g1.globo.com/mundo/renuncia-sucessao-papa-bento-xvi/noticia/2013/02/na-ultima-audiencia-bento-xvi-diz-que-papado-teve-aguas-agitadas.html. Acesso em 12 abr. 2013.

Dez atitudes de humildade do papa Francisco. Rio de Janeiro (2013). Disponível em: https://oglobo.globo.com/mundo/dez-atitudes-de-humildade-do-papa-francisco-10008671. Acesso em 23 jul. 2017.

GONZALEZ, L. Estar no mundo, sem ser do mundo: alguns casos da Jornada Mundial da Juventude (JMJ) Rio 2013. Tese (Doutorado em Ciências Sociais) - PPCIS-UERJ, 2016.

HODKINSON, P. Media, Culture and Society - an introduction. London: Sage Publications, 2010.

JOVENS CATÓLICOS. Rio de Janeiro (2015). Disponível em: http://jovenscatolicos.com. br/. Acesso em 3 jan. 2016.

JOVENS CONECTADOS. Instituto debaterá questões de juventude. Brasília, 2014. Disponível em: http://jovensconectados.org.br/instituto-debatera-questoes-da-juventude.html. Acesso em 12 mar. 2016.

Ao Comitê organizador da JMJ, Papa repete: “Os brasileiros roubaram o meu coração”. Brasília (2014). Disponível em: http://jovensconectados.org.br/ao-comite-organizador-da-jmj-papa-repete-os-brasileiros-roubaram-o-meu-coracao.html. Acesso em 13 out. 2015.

MARIZ, C. L.; GRACINO, P. As novas configurações da religião no século XXI: um inventário sobre jovens participantes em megaeventos religiosos. Projeto apresentado à FAPERJ, 2013. Mimeo.

MARIZ, C. L. Comunidades de vida no espírito - juventude e religião. Tempo social, v. 17/2, 2005, p. 253-273.

MARTINO, L. M. S. Mídia, Religião e Sociedade: Das palavras às redes digitais. São Paulo: Paulus, 2017.

NEWS.VA. Na Via Sacra, Papa Francisco fala dos jovens que perderam a fé na Igreja pela incoerência de seus filhos e recorda das vítimas do incêndio em Santa Maria. Rio de Janeiro (2013). Disponível em: http://www.news.va/pt/news/na-via-crucis-papa-franciscofala-dos-jovens-que-p. Acesso em 12 jan. 2014. 
PEW CENTER. Religion in Latin America. Washington (2013). Disponível em: http:// www.pewforum.org/2014/11/13/religion-in-latin-america/. Acesso em 21 ago. 2015.

Six Months Into Papacy, Large Majority of Catholics Continue To Express Favorable View of Pope Francis. Washington (2013). Disponível em: http://www.pewforum. org/2013/09/12/six-months-into-Papacy-large-majority-of-catholics-continue-to-express-favorable-view-of-pope-francis/. Acesso em 28 jan. 2014.

PORTAL PUC RIO DIGITAL. Dom Orani: solidariedade deve se perpetuar. Rio de Janeiro (2010). Disponível em: http://puc-riodigital.com.puc-rio.br/Jornal/Campus/Dom-Orani\%3Asolidariedade-deve-se-perpetuar-6503.html. Acesso em 12 de jan. 2013.

PORTO, T. M. E. As tecnologias de comunicação e informação na escola; relações possíveis... relações construídas. Revista Brasileira de Educação, v. 11, n. 31, jan./abr. 2006.

RÁDIO VATICANO. Papa em Varginha: Que bom poder estar com vocês aqui!, Vaticano (2013). Disponível em: http://br.radiovaticana.va/news/2017/07/25/papa_em_varginha_que_ bom_poder_estar_com_voc\%C3\%AAs_aqui!/1326923. Acesso em 25 jul. 2017.

ROLling STONE. São Francisco (2014). Pope Francis: The Times They Are A-Changin'. Disponível em: http://www.rollingstone.com/culture/news/pope-francis-the-timesthey-are-a-changin-20140128. Acesso em 20 jan. 2014.

SANTA SÉ. Biografia do Santo Padre Francisco. Vaticano (2013). Disponível em: https:// w2.vatican.va/content/francesco/pt/biography/documents/papa-francesco-biografia-bergoglio. html. Acesso em 8 abr. 2015.

Carta encíclica Lumen Fidei. Vaticano (2013). Disponível em: http://w2.vatican. $\mathrm{va} /$ content/francesco/pt/encyclicals/documents/papa-francesco_20130629_enciclica-lumenfidei.html. Acesso em 24 jul. 2013.

Encontro com os jovens argentinos - palavras do Santo Padre. Vaticano (2013). Disponível em: https://w2.vatican.va/content/francesco/pt/speeches/2013/july/ documents/papa-francesco_20130725_gmg-argentini-rio.html. Acesso em 15 dez. 2013.

Festa de Acolhida dos Jovens - Saudações e Homilia. Praia de Copacabana, Rio de Janeiro, 25/07/2013. Disponível em: https://w2.vatican.va/content/francesco/pt/speeches/2013/july/documents/papa-francesco_20130725_gmg-giovani-rio.pdf. Acesso em 15 out. 2013.

Palavras do Santo Padre. Vaticano (2013). Disponível em: https://w2.vatican.va/ content/francesco/pt/speeches/2013/july/documents/papa-francesco_20130726_gmg-viacrucis-rio.html. Acesso em 24 jul. 2013.

TEIXEIRA, F.; MENEZES, R. (Org.). Religiões em movimento - o censo de 2010. Petrópolis: Vozes, 2013.

THE GUARDIAN. 'Vatileaks' scandal widens as pope's butler vows to help investigators. Londres (2012). Disponível em: https://www.theguardian.com/world/2012/may/28/ vatileaks-scandal-pope-butler-gabriele. Acesso em 15 ago. 2013.

THE WASHINGTON TIMES. New York's Cardinal Dolan accused of shielding pedophile priests: documents. Washington (2013). Disponível em: http://www.washingtontimes.com/ news $/ 2013 /$ jul/2/new-yorks-cardinal-dolan-accused-shielding-pedophi/. Acesso em 2 jul. 2015. 
TIME MAgAZINE. Nova Iorque (2013). Pope Francis, The People's Pope. Disponível em: http://poy.time.com/2013/12/11/person-of-the-year-pope-francis-the-peoples-pope/. Acesso em 20 jan. 2014.

UOL NOTÍCIAS. Papa argentino "vai nos entender melhor", diz jovem brasileira. São Paulo (2013). Disponível em: https://noticias.bol.uol.com.br/internacional/2013/03/13/papa-argentino-vai-nos-entendermelhor-diz-jovem-brasileira.jhtm. Acesso em 20 mar. 2013.

VASQUEZ, M.; FERNANDES, S. R. A. Just what kind of revolution is Pope Francis calling for? Religion Dispatches. Estados Unidos, 2013.

VATICAN. Visita Apostólica do papa Francisco ao Brasil por ocasião da XXVIII Jornada Mundial da Juventude. Disponível em: https://w2.vatican. $\mathrm{va} /$ content/francesco/pt/speeches/2013/july/documents/papa-francesco_20130725_gmg-argentini-rio.html. Acesso em 26 jul. 2017.

YOUCAT BRASIL. O prefácio do Papa Bento XVI (2015). Disponível em: http://www. youcat.org.br/o-prefacio-do-papa-bento-xvi/. Acesso em 21 mar. 2015.

ZENIT. Vocês são o campo da fé! Vocês são os atletas de Cristo! Taubaté, 2013. Disponível em: https://pt.zenit.org/articles/voces-sao-o-campo-da-fe-voces-sao-os-atletas-de-cristo/. Acesso em 19 dez. 2014.

O Vozes Católicas foi um dos legados oficiais da JMJ Rio 2013. Taubaté (2014). Disponível em: https://pt.zenit.org/articles/brasil-o-vozes-catolicas-foi-um-dos-legados-oficiais-da-jmj-rio-2013/. Acesso em 20 nov. 2014.

Submetido em: 5-8-2016

Aceito em: 3-8-2017 